\title{
Energy Harvesting: A Toxic Free and Reliable Power Source for Implantable Microsystems
}

\author{
Suhaib Ahmed* and Vipan Kakkar \\ Department of Electronics and Communication Engineering, Shri Mata Vaishno Devi University, India
}

Received: October 13, 2017; Published: October 20, 2017

*Corresponding author: Suhaib Ahmed, Department of Electronics and Communication Engineering, Shri Mata Vaishno Devi University, Katra, India, Email: sabatt@outlook.com

\section{Editorial}

The implantable medical devices require constant power source and for this requirement, batteries have been developed that has enabled the successful deployment of the devices and their treatment of human disease. While the functional requirements for the batteries used to power these devices vary with the type of device and therapy, there are some characteristics that are demanded by all applications. The batteries must have high life span, be safe during installation and use, have predictable performance that can be interrogated to provide state of discharge information and be highly reliable [1]. Additionally, the batteries must have high volumetric energy density to enable the design of

Table 1: Comparison of Different Batteries Used in Implantable Medical Devices.

\begin{tabular}{|c|c|c|c|}
\hline Battery & $\begin{array}{c}\text { Open circuit cell potential } \\
\text { (V) }\end{array}$ & $\begin{array}{c}\text { Nominal cell potential (V) } \\
\text { Volumetric Capacity } \\
\text { (mAh/cm3) }\end{array}$ & $\begin{array}{c}\text { Energy Density (mWh/g) } \\
\text { Li/I2 }\end{array}$ \\
\hline $\mathrm{Li} / \mathrm{MnO} 2$ & 3.3 & 2.8 & 21041 \\
\hline $\mathrm{Li} / \mathrm{CFX}$ & 3.1 & 3 & $230-270$ \\
\hline $\mathrm{Li} / \mathrm{SVO}$ & 3.2 & 3.2 & 2335 \\
\hline $\mathrm{C} / \mathrm{LiCoO2}$ & 4.2 & 3.9 & 1510 \\
\hline
\end{tabular}

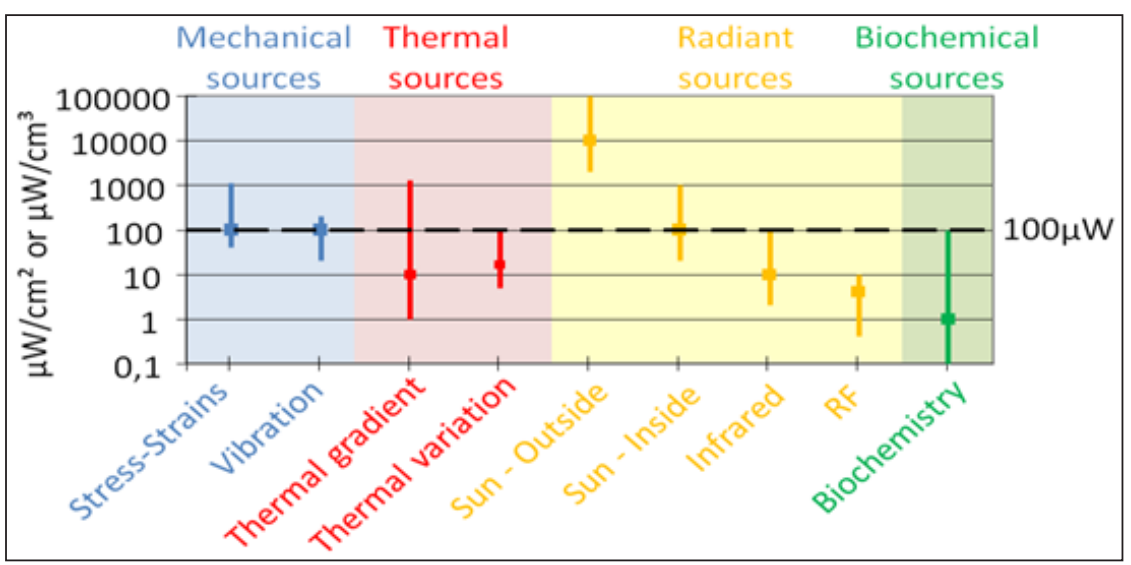

Figure 1: Comparison of power densities of different ambient energy sources. 
This range of batteries provides the appropriate power levels as demanded by a specific medical device varying from microampere to ampere level currents. Successful development and implementation of these battery types has helped enable implanted biomedical devices and their treatment of human disease. Among these, Li/I2 has proved to be safer and more reliable than others for use in pacemakers and hence used widely in the last 4 decades [13]. However, these batteries suffer from limited life span and hence require replacement by surgery which is inconvenient to the patient. Hence an alternate energy source is required to continuously power these implants. One such approach which can address the abovementioned problem is Energy Harvesting $[14,15]$. It is the process of scavenging out energy from different sources in the ambient environment. Various harvesters are being proposed to harvest energy for implantable devices. Some of the recently reported harvesters can be studied in [15-21]. The form of energy used by the harvester to scavenge the power, defines the type of energy harvesting. There are four main ambient energy sources available viz., mechanical energy due to vibrations and deformations (electrostatic, piezoelectric and electromagnetic), thermal energy (temperature variations and gradients), radiant energy (sun, IR, RF) and biochemical (bio-fuel cells). A comparison of the power densities of these different energy sources is presented in Figure 1 [15,22].

Although research is being carried out on designing different structures of energy harvesters to generate as much power as possible, there are still some aspects that need to be investigated before finally implanting the harvester inside the body. One such area is the stability of the harvester. For example in electret-based electrostatic harvesters, the electret stability degraded at high temperature and humidity and at higher surface potentials which can reduce the life-span of the harvester. Another aspect that has to be investigated is the toxicological effect of the harvester, if any. But given the trend of the energy harvested by different structures being proposed, the practical application of the harvesters in implantable microsystems as a reliable power source will certainly be a reality.

\section{References}

1. Bock DC, AC Marschilok, KJ Takeuchi, ES Takeuchi (2012) Batteries used to power implantable biomedical devices. Electrochimica actas 84: 155164.

2. Kim DH, N Lu, R Ma, YS Kim, RH Kim, et al. (2011) Epidermal electronics. science 333(6044): 838-843.

3. Cao H, S Rao, SJ Tang, HF Tibbals, S Spechler, et al. (2013) Batteryless implantable dual-sensor capsule for esophageal reflux monitoring. Gastrointestinal endoscopy 77(4): 649-653.

4. Holmes CF (2001) The role of lithium batteries in modern health care. Journal of power sources 97: 739-741.

5. Cao H, F Yu, Y Zhao, N Scianmarello, J Lee, et al. (2014) Stretchable electrochemical impedance sensors for intravascular detection of lipidrich lesions in New Zealand White rabbits. Biosensors and Bioelectronics 54: 610-616.
6. Cao H, AL Li, CM Nguyen, YB Peng, JC Chiao (2012) An integrated flexible implantable micro-probe for sensing neurotransmitters. IEEE Sensors Journal 12(5): 1618-1624.

7. Greatbatch W, C Holmes, E Takeuchi, S Ebel (1996) Lithium/carbon monofluoride (LI/CFx): a new pacemaker battery. Pacing and clinical electrophysiology 19(11): 1836-1840.

8. Davis S, ES Takeuchi, W Tiedemann, J Newman (2008) Simulation of Pulse Discharge of the Li-CF x System. Journal of The Electrochemical Society 155(1): 24-28.

9. Takeuchi ES, P Piliero (1987) Lithium/silver vanadium oxide batteries with various silver to vanadium ratios. Journal of power sources 21(2): 133-141.

10. Crespi A, C Schmidt, J Norton, K Chen, P Skarstad (2001) Modeling and characterization of the resistance of lithium/SVO batteries for implantable cardioverter defibrillators. Journal of the Electrochemical Society 148(1): 30-37.

11. Gomadam PM, DR Merritt, ER Scott, CL Schmidt, PM Skarstad, et al. (2007) Modeling LV CF x-SVO Hybrid-Cathode Batteries. Journal of the Electrochemical Society 154(11): 1058-1064.

12. Chen K, DR Merritt, WG Howard, CL Schmidt, PM Skarstad (2006) Hybrid cathode lithium batteries for implantable medical applications. Journal of power sources 162(2): 837-840.

13. Wei X, J Liu (2008) Power sources and electrical recharging strategies for implantable medical devices. Frontiers of Energy and Power Engineering in China 2(1): 1-13.

14. Koul S, S Ahmed, V Kakkar (2015) A comparative analysis of different vibration based energy harvesting techniques for implantables. in Computing, Communication \& Automation (ICCCA), International Conference on. IEEE: 979-983.

15. Ahmed S, V Kakkar (2017) An Electret-based Angular Electrostatic Energy Harvester for Battery-less Cardiac and Neural Implants. IEEE Access 5: 19631-1943.

16. Kulah H, N Goksu, L Beker, (2017) Energy harvesting cochlear implant. Google Patents.

17. Kerzenmacher S, J Ducrée, R Zengerle, F Von Stetten (2008) Energy harvesting by implantable abiotically catalyzed glucose fuel cells. Journal of Power Sources 182(1): 1-17.

18. Chen Z, MK Law, PI Mak, RP Martins (2017) A single-chip solar energy harvesting IC Using integrated photodiodes for biomedical implant applications. IEEE transactions on biomedical circuits and systems 11(1): 44-53.

19. Moon E, D Blaauw, JD Phillips (2017) Subcutaneous Photovoltaic Infrared Energy Harvesting for Bio-implantable Devices. IEEE Transactions on Electron Devices 64(5): 2432-2437.

20. Jay S, M Caballero, W Quinn, J Barrett, M Hill (2016) Characterization of piezoelectric device for implanted pacemaker energy harvesting. in Journal of Physics: Conference Series IOP Publishing 757(1)

21. Katic J, S Rodriguez, A Rusu (2017) A High-Efficiency Energy Harvesting Interface for Implanted Biofuel Cell and Thermal Harvesters. IEEE Transactions on Power Electronics 99: 1.

22. Boisseau S, G Despesse, BA Seddik (2012) Electrostatic Conversion for Vibration Energy Harvesting, in Small-Scale Energy Harvesting. InTech: France 91-134. 


$\begin{array}{ll}\text { BIOMEDICAL } & \text { Assets of Publishing with us } \\ \text { RESEARCHES } & \text { - Global archiving of articles } \\ & \text { - Immediate, unrestricted online access } \\ & \text { - Authorous Peer Review Process } \\ & \end{array}$

